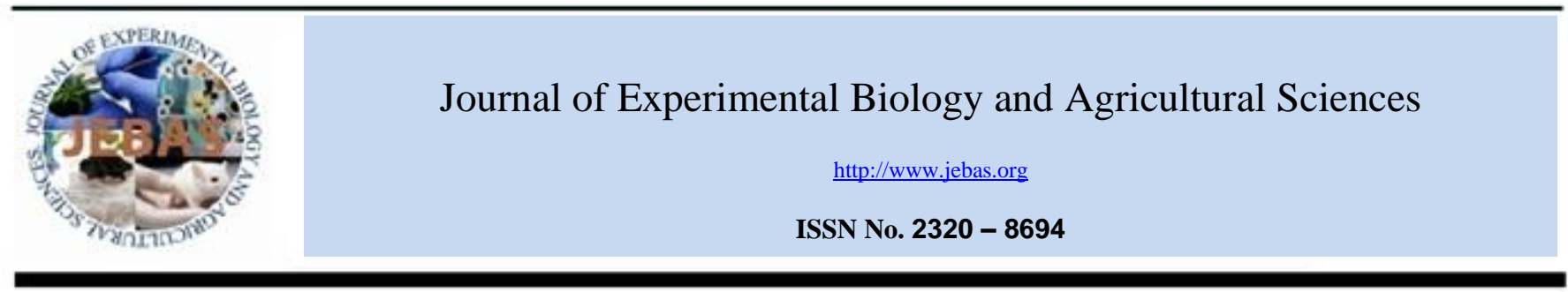

\title{
EXPLORING ALTERNATIVES TO ANTIBIOTICS AS HEALTH PROMOTING AGENTS IN POULTRY- A REVIEW
}

\section{Ajit Singh Yadav ${ }^{1, *}$, Gautham Kolluri ${ }^{1}$, Marappan Gopi ${ }^{1}$, Kumaragurubaran Karthik $^{2}$, Yashpal Singh Malik $^{2}$ and Kuldeep Dhama ${ }^{2}$}

${ }^{1}$ ICAR-Central Avian Research Institute, Izatnagar-243122, UP, India

${ }^{2}$ ICAR-Indian Veterinary Research Institute, Izatnagar-243122, UP, India

Received - May 05, 2016; Revision - May 09, 2016; Accepted - May 21, 2016

Available Online - May 25, 2016

DOI: http://dx.doi.org/10.18006/2016.4(3S).368.383

\begin{abstract}
KEYWORDS
Poultry production

Antibiotics

Probiotics

Prebiotics

Synbiotics

Organic acids

Plant extracts

Phytobiotics

Herbs

ABSTRACT

Poultry industry has undergone rapid growth during last three decades. For which even higher usage of antibiotics, both as growth promoters as well as therapeutic agents, has been adopted. However, due to the fear of resistance development in bacterial populations to antibiotics, presence of antibiotic residues in poultry products and increasing consumer demand for products free from antibiotic residues, search for alternatives that could replace antibiotics without causing loss to productivity or product quality has accelerated. Such alternatives in poultry include the use of organic acids, probiotic microorganisms, prebiotic substrates that benefit proliferation of beneficial bacterial populations or synbiotic (combinations of prebiotics and probiotics) ensuring better production and maintaining health of the birds. Others include vitamins and minerals, herbal drugs, plant extracts, phytobiotics and antimicrobial peptides. Probiotic organisms provides competition to pathogenic organisms for intestinal colonizing sites, reduce the diversion of nutrients for harmful microbes and the toxins produced by them and stimulates the immune systems. Similarly, prebiotic offers an alternative, as it alters the intestinal microbes and immune system to reduce colonization by pathogens and allows proliferation of beneficial microflora in the gut. Even using synbiotic is a better strategy for enhancing poultry production, however, more research is needed for selection of probiotic, prebiotics or synbiotics either alone or in combination that can result in the selection of strains capable of performing effectively in the gastrointestinal tract. The contents of this review will be useful for researchers to enrich their knowledge on alternatives of antibiotics in poultry birds without compromising performance of birds and bird welfare.
\end{abstract}

\section{* Corresponding author}

E-mail: asinghcari@gmail.com (Ajit Singh Yadav)

Peer review under responsibility of Journal of Experimental Biology and Agricultural Sciences.

Production and Hosting by Horizon Publisher India [HPI] (http://www.horizonpublisherindia.in/).

All rights reserved.
All the article published by Journal of Experimental Biology and Agricultural Sciences is licensed under a Creative Commons Attribution-NonCommercial 4.0 International License Based on a work at www.jebas.org.

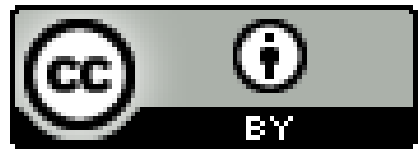




\section{Introduction}

Poultry industry has seen an unparalleled growth during last three decades and is now recognized as one of the fastest growing component of agriculture sector. This has happened due to increased consumption of eggs and meat with their easy availability, relatively inexpensive cost and rich in all essential nutrients which can meet the deficiencies of critical dietary minerals, vitamins and amino acids (Dhama et al., 2014a). High growth contributing factors have been exploited for optimal genetic potential of birds, availability of quality of the feed, providing optimal environmental condition and preventing disease outbreaks. In recent years, gut health of poultry birds has been the area of intense studies in poultry production for higher production (Rinttila \& Apajalahti, 2013), as this is the main site where nutrient uptake takes place. The gastro-intestinal tract is the organ which exposed to majority of environmental pathogens next to skin (Yegani \& Korver, 2008). Thus, the main thrust in poultry production is to maintain sound gut health and function ensuring proper health and production. Due to impaired gut function and health, both the digestion and absorption of nutrients are affected and thus the overall health and performance of birds will be compromised which ultimately affect economics of poultry production.

Antibiotics have been widely used in poultry production worldwide due to their easy availability and low cost. It has revolutionized the intensive poultry to promote growth, production and feed conversion efficiency by improving gut health and reduction of sub-clinical infections. Antibiotics inclusion at low concentration augment gut health by reducing the pathogen load and helps in preventing sub-clinical infection normally present continuously in the birds even in the well-organized poultry units. The beneficial effects of using antibiotics include the thickening of intestine which leads to more nutrient absorption. Thus, it can spare the critical nutrients for the host by reducing the competition between host and pathogens and by preventing the microbial adherence and invasion to the gut wall lowers the production of toxic amines thus preventing stress to birds. The effect of antibiotics is more pronounced when the birds are kept under unhygienic conditions and are maintained on relatively vitamins and or amino acid imbalance /deficient diet that clearly indicate the nutrient sparing effect of antibiotics. Penicillin G was the first antibiotic introduced in veterinary medicine in 1947 for use as intramammary infusions. Since that time the use of antibiotics has become an integral part of managing animal health in agriculture. Antibiotics are administered to food animals including poultry by several different routes including injections, orally in feed and water. Commonly employed antibiotics for preventative and therapeutic purposes in poultry are chlortetracycline (Athar \& Ahmad, 1996; Kodimalar et al., 2014), furazolidones (Oluwasile et al., 2014), fluroroquinolones (Anderson \& Macgowan 2003; Luangtongkum et al., 2006; Martinez et al. 2006; Billah et al., 2015), oxytetracycline (Adel Feizi, 2013), sulphonamides
(Persoons et al., 2012), gentamicin (Alm El Dein \& Elhearon, 2010), Quinolones (Naeem et al., 2006).

Despite tremendous beneficial use, the practice of using antibiotics in poultry is being questioned, owing to increased resistance to antibiotics (Tiwari et al., 2014a). The mechanism of resistance development in antibacterial population happens when an antibiotic is applied in food animal at sub-therapeutic level, which results in eliminating the sensitive population of bacteria leaving the variants having unusual traits and resists the effect. These resistant bacteria then multiply becoming the predominant. The resistant population so produced transmits the resistance which is genetically defined to subsequent progeny and also to other bacterial strains via mutation or plasmid mediated (Catry et al., 2003). Human may get exposure to such resistant bacteria population through consumption and handling of meat contaminated with such pathogens (Van den Bogaard \& Stobberingh, 2000). Once these are acquired, such resistant bacteria can colonize the intestinal tract of human and the genes coding resistance to antibiotics in these bacteria can be transferred to other bacteria belonging to the endogenous microflora of humans (Ratcliff, 2000; Stanton, 2013), thus causing impediments in effective treatment of bacterial infections.

Because of drug resistance associated with use of antibiotics in poultry production, there has been a big push to find alternative treatment methods for common poultry ailments. The alternatives to antibiotics are needed to maintain the gut health and performance by controlling pathogens and increased nutrient digestion and absorption. Some of the ways to minimize antibiotics in poultry include use of whole grain cereals, live microbial cultures, use of fermentable sugars and processing/ sterilization of feeds. Prominent alternatives in poultry production include organic acids, probiotics, prebiotics, synbiotics, herbal drugs, vitamins, minerals and plant extracts (essential oils) etc. (Dhama et al., 2014a). The attributes of alternatives are as follows:

1. It should improve performance effectively

2. It should have little therapeutic use in human or veterinary medicine

3. It should not cause deleterious disturbances of the normal gut flora

4. It should not be involved with transferable drug resistance

5. It should not be absorbed from the gut into edible tissue

6. It should not cause cross-resistance to other antibiotics at actual use level

7. It should not promote Salmonella shedding

8. It should not be mutagenic or carcinogenic

9. It should not give rise to environmental pollution

10. It should be readily biodegradable

11. It should be non-toxic to the birds and its human handlers. 
Even combined supplementation of prebiotics and probiotics which is referred as symbiotic is a better strategy for enhancing production, however, more research is needed for selection of probiotic, prebiotics or synbiotics either alone or in combination that can result in the selection of strain/s capable of performing effectively in the gastrointestinal tract. The present review discusses the valuable alternatives to antibiotics as health promoting agents in poultry production system, including of organic acids, probiotics, prebiotics, synbiotics, vitamins and minerals herbal drugs, plant extracts, phytobiotics and antimicrobial peptides. The contents of the review will be useful for researchers to conduct more research on alternatives of antibiotics in poultry birds without compromising performance of birds and bird welfare.

\section{Alternatives to antibiotics as health promoting agents in poultry}

\subsection{Organic acids}

Organic acids are being considered as one of the effective alternative of the antibiotics in recent years because of their antimicrobial activity against wide range of pathogenic bacteria because of their ability to induce a $\mathrm{pH}$ reduction in the gut and these can improve nutrient utilization in poultry diets (Eidelsburger et al., 1992; Boling et al., 2000; Kil et al., 2011). These have been used either as single acid or combination of several acids (Wang et al., 2009). Use of organic acids and their salts in poultry has been permitted as safe by the European Union (Adil et al., 2010).

Basically, organic acid includes carboxylic acids and fatty acids having a chemical formula of $\mathrm{R}-\mathrm{COOH}$, where $\mathrm{R}$ represents chain length of the acids. In poultry feeding, organic acids of short chain length like formic (C1), acetic (C2), propionic (C3) and butyric acid (C4) had been tried more often. Other carboxylic acids used include citric, lactic, fumaric, malic and tartaric acids (Dibner \& Buttin, 2002). Generally, organic acids are weak acids and these are dissociated only partly and most organic acids possessing antimicrobial activity have a $\mathrm{pKa}$ value (defined as the $\mathrm{pH}$ at which the acid is half dissociated) in the range of 3 to 5 . Organic acids are also available as calcium, potassium or sodium salts. The salts are being preferred as these are odorless and easy to handle during feed processing owing to their less volatile property and solid in their state. Further, the organic acids are less corrosive in nature and more soluble in water (Huyghebaert et al., 2011).

These can be used both in water and feed. The proposed sequential mechanisms of action as bactericidal exhibited by organic acid are as follows: Initially acid form of organic acids can penetrate across the bacteria cell wall and subsequently penetrated organic acids within bacterial cells dissociate into the conjugated base form (non-protonated form) leading to a reduction in cellular $\mathrm{pH}$ and the decreased intracellular $\mathrm{pH}$ creates a stressful environment for bacteria leading to cellular dysfunctions thereby preventing bacterial growth (Mani-
Lopez et al., 2012). On other hand, sorbic acid increases the permeability of the bacterial cell as well as causing interference with membrane proteins (Abdelrahman, 2016).

Role of organic acids in poultry production include lowering down the $\mathrm{pH}$ of the poultry feed and gastrointestinal tract (GIT), improved nutrient utilization in diets by increasing nutrient retention, preventing the growth of pathogens (Afsharmanesh \& Pourreza, 2005; Mroz, 2005). Capacity to decrease $\mathrm{pH}$ in the feed and GI tract by the organic acid likely dependent on the $\mathrm{pH}$ conditions of the GIT and $\mathrm{pKa}$ values of the organic acid used (Kim et al., 2005). The $\mathrm{pH}$ reduction in GI tract is more pronounced in the upper part. Application in drinking water ensures pathogen reduction and subsequently crop besides regulating normal gut flora (Açkgöz et al. 2011; Hamed \& Hassan 2013).

Organic acids are readily absorbed in the proximal part of gastro-intestinal tract. Their ability to acidify the gut environment results in increased intestinal protease enzyme activity which in-turn increases the nutrient digestibility and utilization. This may be due to fact that acidic digesta may be retained for longer time in GI tract, and therefore provide more time for nutrient digestion in the GIT (Kidder \& Manners, 1978; Mayer, 1994). Inhibition of undesirable microbes not only prevents the accumulation of toxic metabolites, but also spares more nutrients available for the host, ensuring higher feed utilization efficiency. Moreover, stabilization of intestinal $\mathrm{pH}$ also increases the efficacy of all digestive enzymes. Organic acids are used in feed sanitation programme, acting as feed additives and preservative. By preventing the growth of pathogenic bacteria it prevents the feed deterioration and extends the shelf-life of perishable food ingredient.

Organic acids commonly used to reduce the pathogenic microbial load (like Salmonella and Escherichia coli) include short chain fatty acids, volatile fatty acids and weak carboxylic acids. Organic acids also reduce the colonization of pathogens on intestinal wall, preventing damage to epithelial cells. Daily application of short chain fatty acids increases epithelial cell proliferation; quick repairing of intestine, increased villous height and in turn increased absorptive capacity. Medium chain fatty acids (MCFA) destroys the bacteria by penetrating its phospholipid layer and alters the cell membrane through the formation of pores resulting in leakage of contents (Hermans \& De Laet, 2014).

It provides an early pathogen barrier for the inhabiting pathogens. Propionic acid is an effective mold inhibitor (Zha \& Cohen, 2014) and can completely inhibit feed mycotoxin. Continuous feeding of propionic acid to chicks reduced Salmonella Gallinarum count of crop and caecal contents. Addition of $0.36 \%$ Calcium formate also reduced Salmonella level both in carcass and caecal samples. 
Akyurek et al. (2011) observed increase in Lactobacilli population and reduction in coliforms and Clostridia in ileum in broilers fed blends of organic acids than the antibiotic groups. Similarly, reduction is Salmonella in caecum through synthesis of antimicrobial peptides in chickens fed with acetate, propionate and butyrate salts (Sunkara et al., 2011; Sunkara et al., 2012). Organic acids cocktail (Hassan et al., 2010; Hamed \& Hassan, 2013) is reported to have more synergistic effect with better efficiency compared to antibiotic growth promoters against intestinal colonized pathogens viz. $E$. coli, Salmonella. N-heterocyclic dicarboxylic acids and pyridyl-mercapto-thiadiazoles are the new generation organic acid types as a future broad-spectrum inhibitors of the metallob-lactamases (MbLs) which can be used in conjunction with beta lactam antibiotics for counteracting drug resistant serotypes (Abdelrahman, 2016).

The availability of calcium especially in egg producing chickens is influenced by the presence of oxalic acid which is present in plant sources. This oxalic acid form insoluble calcium oxalate salts (Jadhav et al., 2015). An increase in calcium solubility and availability was observed in the studies of Tang et al. (2007) who fed the birds with Lactobacillus strains which is attributed to its ability to reduce the gut $\mathrm{pH}$ due the production of lactic and acetic acids.

Organic acids also reduce contamination of litter with pathogens and diminish the risk of re-infection, thus reducing the bacterial challenge to poultry birds. Organic acids possess potent property to reduce $\mathrm{pH}$ and have been found to reduce pathogens in GI tract, however, more studies are needed to elucidate the mode of action of dietary organic acids and their effects on growth performance of broiler chickens by various combinations of acids and their concentration in feed or drinking water.

\subsection{Probiotics}

Probiotics are either single and/or mixture of live microbial culture which promote health benefits to the host (Fuller, 1992). Mode of probiotic bacteria involves competition with receptor sites in the intestinal tract, production of specific metabolites (short organic fatty acids, hydrogen peroxide, other metabolites possessing antimicrobial activity) and immune stimulation effect (Madsen et al., 2001; Sherman et al., 2009). Microorganisms used as probiotics include Lactobacillus, Streptococcus, Enterococcus, Bacillus, Clostridium, Bifidobacterium species and E. coli while yeast and fungus used as probiotics include Saccharomyces cerevisiae and Aspergillus oryzae (Fuller, 1999). Bacteria and yeasts have been included as spores or as living microorganisms. Probiotics classified as non-colonizing species such as Saccharomyces cerevisiae and Bacillus spp. (spores) while colonizing species include Lactobacillus and Enterococcus spp. Saccharomyces known to offer a source of good quality protein and B complex vitamins. Due to immunomodulatory properties, yeast extract, the non-antibiotic functional product is suggested to be the potential non-antibiotic alternative for decreasing pathogenic bacteria in turkey production (Huff et al., 2010). Currently, yeast cell derivatives are gaining importance as zootechnical feed additives (Świątkiewicz et al., 2014). Similarly, feeding of Aspergillus awamori (0.05\%) improved growth performance through the release of growth promoters (Yamamoto et al., 2007) and meat quality by increasing unsaturated fatty acid content in breast meat (Saleh et al., 2012) of broiler chickens.

The reason behind the use of probiotics has been primarily to establish normal intestinal flora with broad target of prevention or minimizing the disturbances caused by enteric pathogens (Dhama et al., 2008). Probiotics are not the substitute of antibiotics in birds with serious infections but these are useful in restoring the normal bacterial population. The effect of probiotic depend on physiological state of the bird, type and concentration of probiotic strain, persistence in intestine, ability to survive during feed processing and gastrointestinal track and compatibility with natural microbiota of the intestine. The strain of probiotic to be called as ideal should be resistant to acid, bile salts and digestive enzymes. It should also possess property of rapid multiplication so as to produce microbial population required for producing desirable effect. Further, the strain used should not impart antibiotic resistance into the intestinal microflora (Seema \& Johri, 1992; Pal \& Chander, 1999; Dhama et al., 2011; Mookiah et al., 2014).

Benefits of probiotics:

1. Improves the health of gut health by upholding a desired equilibrium in its microbial population and reducing incidences of diarrhea.

2. Inhibits growth of pathogens and reduces the mortality

3. Results in better feed conversation efficiency

4. Improves growth rate and body weight gain

5. Improves the digestive enzymes and in turn nutrient absorption

6. Reduces circulating cholesterol level through regulation of lipid metabolism

7. Enhances efficacy of vaccines

8. Plays important role in fast detoxification of mycotoxins

9. Reduce stress associated with administration of antibiotics, temperature, vaccination, transportation etc.

10. Synthesis Vitamin B complex vitamins

11. Improves litter quality via. enteric and also litter ammonia production

12. Enhances the intestinal short chain fatty acids which could alter the microbial composition in gut

13. Leaves no residues effects in products

14. Decreases environmental pollution

One mode of action associated with probiotics is the competitive exclusion as these produce some substances which inhibit growth of pathogens. Moreover, the pathogens also compete with them for a place in the intestinal epithelium. 
The substances produced by probiotic bacteria are short-chain organic acids (lactic, acetic, propionic), hydrogen peroxide, bacteriocins which includes nisin, acidolina, lacocydyna, lacatcyna, reutryna, entrocine, laktoline. Bacteriocins produced by probiotics possess a high antibacterial activity against Salmonella, Campylobacter, Escherichia coli and Clostridium perfringens. Probiotic (s) supplementation in feed is considered to be the potential candidate strategy for controlling necrotic enteritis (Mahmood et al., 2014) and Eimeria acervulina and E. tenella with effective reduction of oocysts (Lee et al., 2007).

Another mode of action of probiotics is by stimulation of immune system due to their ability of adhesion to the intestinal mucosa which allows creating a natural barrier for entry of pathogens thereby enhancing immunity. Further, probiotic stimulation of the immune system exhibited higher production of immunoglobulins, stimulation macrophages and lymphocytes activity and also by augmentation of the production of $\gamma$-interferon (Yang \& Choct, 2009). Ensuring antibiotic efficacy without therapeutic involvement, consumer's demand for antibiotic free products and animal welfare promotion are considered to be the key drivers for increased use of probiotics in poultry production currently (Blanch, 2015).

A latest approach in probiotics feeding especially in poultry is the in ovo injection of probiotic culture. As the newly hatched chick will have a sterile gastro-intestinal tract, so it harbors the microflora when they are exposed to various microbes in the environmental on its arrival to its rearing house system. Colonization in chicks takes place after hatching (AmitRomach et al., 2004) but presence of few numbers of microbes in their intestine during pre-natal stage itself was reported by Pedroso (2009) and Bohorquez (2010). Various available scientific reports showed that feeding of probiotics in birds reduced the impact of various stress conditions. Similarly, the newly hatched chicks are being exposed to different types of stresses like hatching, sexing vaccination, dehydration, starvation, transport, etc. Various in ovo injection studies have shown that embryonic administration of essential amino acids, minerals, carbohydrates, fatty acids reduced the impact of these stress and enhanced the growth performance in broilers. Hence, the administration of probiotic culture in in ovo condition could also be help in overcoming various stresses during early life. In an experiment in broilers, in ovo injection with combination of probiotic organisms at 17.5 days of incubation significantly reduced the Salmonella counts in intestine (de Oliveira, 2014).

\subsection{Prebiotics}

Prebiotics are certain non-digestive feed components that benefit the host by selectively accelerating growth rate and /or proliferation of one or more of a limited number of bacteria in the colon of host so that the health of the gut can be improved. These provide the substrate to the beneficial intestinal microorganisms. The main function associated with prebiotics include alteration of GI microflora, immune stimulation, preventing colon cancer and reducing pathogen invasion, reduction of cholesterol and odor compounds (Cummings \& Macfarlane, 2002), improve gut health through intestinal microbial balance, promotion of enzyme reaction, reduction in ammonia and phenol products and ultimately reducing production cost (Ghiyasiet al., 2007; Khksar et al., 2008; Peric et al., 2009). The predominant prebiotics tried in chickens are gluco-oligosaccharides (GOS), fructo-oligo-saccharides (FOS), mannan-oligo-saccharides (MOS), stachyose and oligochitosan (Jiang et al., 2006). Some attributes for being a good prebiotic include (i) it should neither hydrolyzed nor absorbed in the upper part of the gastrointestinal tract, (ii) induce systemic effects to enhance health of the host and palatable as feed ingredient and (iii) easy to process in large scale.

Addition of prebiotics to poultry diets can minimize the use of antibiotics ultimately reducing bacterial drug resistance (Patterson \& Burkholder, 2003). Further, use of prebiotics in poultry diet can reduce colonization of pathogens such as Escherichia coli, Vibrio cholera, S. Typhimurium, S. Enteritidis etc. (Bailey et al., 1991). Supplementation of oligosaccharides reduced total viable counts in meat and caecum. Prebiotics also promotes the growth of Bifidobacteria and Lactobacillus and reduces the harmful intestinal pathogens (Dhama et al., 2007) Thus, prebiotics can be used as one of the alternative of antibiotics with an aim to improve poultry health and performance through alteration of intestinal microbial population and stimulating immune system by pathogen reduction, however, more studies are needed to elucidate exact role and mode of action as single component or in combination.

The presence of microfloral population in gastro-intestinal tract influences the growth and immune system in chickens. Prebiotics are well known for its ability to enhance the establishment of good microbes (Gibson, 1999; Van Loo et al., 1999) but they also involved in altering the innate immune response through binding with receptors, promotes endocytosis, cytokines and chemokines (Di Barolomeo et al., 2013). Inulin, a polymer of fructose is widely used as prebiotic in both human as well as in animals. Even though, they are indigestible in the intestinal tract but serves as a substrate for the growth of Bifidobacteria (Niness, 1999; Kelly, 2008). Inulin also promotes the production of secretory immunoglobulin A (SIgA) at ileum (Nakamura et al., 2004) and increases the immunity against invading bacteria in the gut (Buddington et al., 2002).

\subsection{Synbiotics}

The mixture of probiotics and prebiotics (synbiotics) which provides the live culture and feeding them from better survival in the bird's intestinal tract (Yang et al., 2009; Gaggia et al., 2010). Fructo-oligosaccharides and bifidobacteria, and lactitol and lactobacilli are the commonly known combinations of pro and prebiotics for use as synbiotics (Yang et al., 2009). 
Microflora of intestine play important role in bird health and if this balance between useful microorganisms gets disturbed, then the health and overall performance of the bird is affected. This invites to explore role of dietary supplementation in the form of prebiotics which can be supplemented to support the growth of beneficial microflora so that production in poultry birds can be enhanced. The supplementation of prebiotics which ensure growth of probiotics is called synbiotics (Huyghebaert et al., 2011). The supplementation of both probiotics and prebiotics could improve the survival and persistence of the useful organism in the gut of birds as specific substrate is available for fermentation (Yang et al., 2009; Adil \& Magray, 2012). Synbiotics were effective in improving the growth of broiler in the diet of chickens (AbdelRaheem et al., 2012; Mookiah et al., 2014). Feeding of synbiotics in broiler chicken was found to have beneficial effect on intestinal morphology and nutrient absorption leading to enhanced performance (Awad et al., 2008; Hassanpour et al., 2013). Very few studies have reported the optimal benefits of synbiotics in poultry ( $\mathrm{Li}$ et al., 2008). Much attention has to be paid to find out the best combination of pro and prebiotic and its subsequent evaluation of their synergistic effects for use as potential synbiotics to ensure maintenance of proper health. An investigation by Madej et al. (2015) in broilers revealed that in ovo administration of inulin (prebiotic) along with Lactobacillus organism altered the development of various immune organs.

\subsection{Vitamins and minerals as growth promoters}

Use of minerals and different vitamins can improve the health status of the poultry which has been proved in the growth of broilers. Minerals and vitamin supplements has increased the poor health status of birds hence increasing the cost benefit ratio of the farm (Prescott \& Baggot, 1993; Peric et al., 2009). Several beneficial effects like improved immune status of the bird increased feed conversion ratio, alteration of beneficial microflora in the gut and intestine. Vitamins like vitamin $\mathrm{C}$ has a major role to reduce stress mainly during summer months, increases feed intake thereby improving metabolism of the feed (Sahin et al., 2003). Other health promoting effects of vitamin $\mathrm{C}$ include reduction of weight loss in birds mainly due to summer stress. Antioxidant vitamin $\mathrm{C}$ is synthesized naturally in birds using an enzyme gulonolactone oxidase that is absent in guinea pigs and human (Lin et al., 2006; Khan, 2011). There is no recommended dose for vitamin $C$ in birds but it may aid in suppressing stress by its antioxidant nature. Study reveals that broilers fed with vitamin $\mathrm{C}$ have shown good performance even under different environmental stress (McKee \& Harrison, 1995). Vitamin C plays an important role in the metabolism of amino acids and promotes the absorption of minerals mainly iron by maintaining them in the reduced ferrous state (McDowell, 1989). Supply of L-arginine along with vitamin $\mathrm{C}$ has improved meat quality in broilers. Another vitamin namely vitamin $\mathrm{E}$ also showed improvement in feed conversion ratio and improved growth performance in poultry. Recommended dose of vitamin E is 5 to $25 \mathrm{IU} / \mathrm{kg}$ of feed for normal functioning of bird though higher doses has also increased poultry's performance (NRC, 1994). Minerals like iron has growth promoter and inhibitor role while phosphorus has role in weight gain of broilers (Abudabos, 2012). Vitamin $\mathrm{Q}$ is most commonly known as ubiquinone due to its distribution among various systems. This is produced endogenously as lipid soluble compound which plays an important role in the energy transformation process inside the cellular mitochondria (Gopi et al., 2015). However, their synthesis will not be sufficient as the age advances. Similarly, in birds especially of fast growing varieties their endogenous production might not be sufficient along with various stress conditions. Gopi (2013) reported an improvement in feed efficiency in broilers fed high energy diet. Moreover, intake of the compound increases their anti-oxidant defence mechanism especially lipophilic systems. Intake of vitamin Q increases the host defence against various microbes bacteria, virus, protozoa (Bliznakov, 1978), activation of macrophages (Hogenauer, 1981) through increased energy availability. Folkers et al. (1982) and Gopi (2013) observed an increase in immunoglobulin $\mathrm{G}$ production and haemeagglutination titer (HI) against Newcastle disease virus in broilers, respectively.

Some of the beneficial applications of probiotics, prebiotics, vitamins, antimicrobial peptides and herbs as growth promoters in poultry are presented in figure. 1.

\subsection{Antimicrobials of plant origin / phytobiotics}

Phytochemicals (commonly known as phytobiotics) as the plant derived compounds have wide range of activities in plants, animals and humans. These compounds are the secondary metabolites produced by the plant which possesses characteristic flavor and taste, primarily for its self-protection from being grazed/ eaten by animals and from pest attack. Over the years, more than 80,000 compounds have been identified so far like phenols, flavonoids, tannins, saponins, essential oils, etc. Initially, these compounds were considered as waste, anti-nutritional and health affecting ones. But, now-adays the approach towards them is changing globally as an antioxidants, digestive enhancer nutraceutical and health promoting substances (Narimani-Rad et al., 2011). Since, the identification of its anti-microbial activity across different groups of organisms (Brut, 2004; Murali et al., 2012) (both gram positive and gram negative organisms). In view of animal production especially in monogastrics (pigs and poultry production) they are mainly used as an alternative antibiotic growth promoter (Khaksar et al., 2012; Karangiya et al., 2016). Although, the exact mechanism of action is not yet known they have been found to favourably alters the gut micro-flora by reducing the number of pathogenic organisms (Salim, 2011). The probable mechanism of action is the through the alteration in membrane permeability to hydrogen ions $\left(\mathrm{H}^{+}\right)$. In addition to its antibacterial activities, it also shows antiviral, antiprotozoan and anti-fungal actions. Their anti-fungal actions are getting more importance as these compounds are now being incorporated in to fungicide preparations which are cost effective as well as environmental friendly (Afzal et al., 2010) and also as fly repellent (Mansour et al., 2011). 


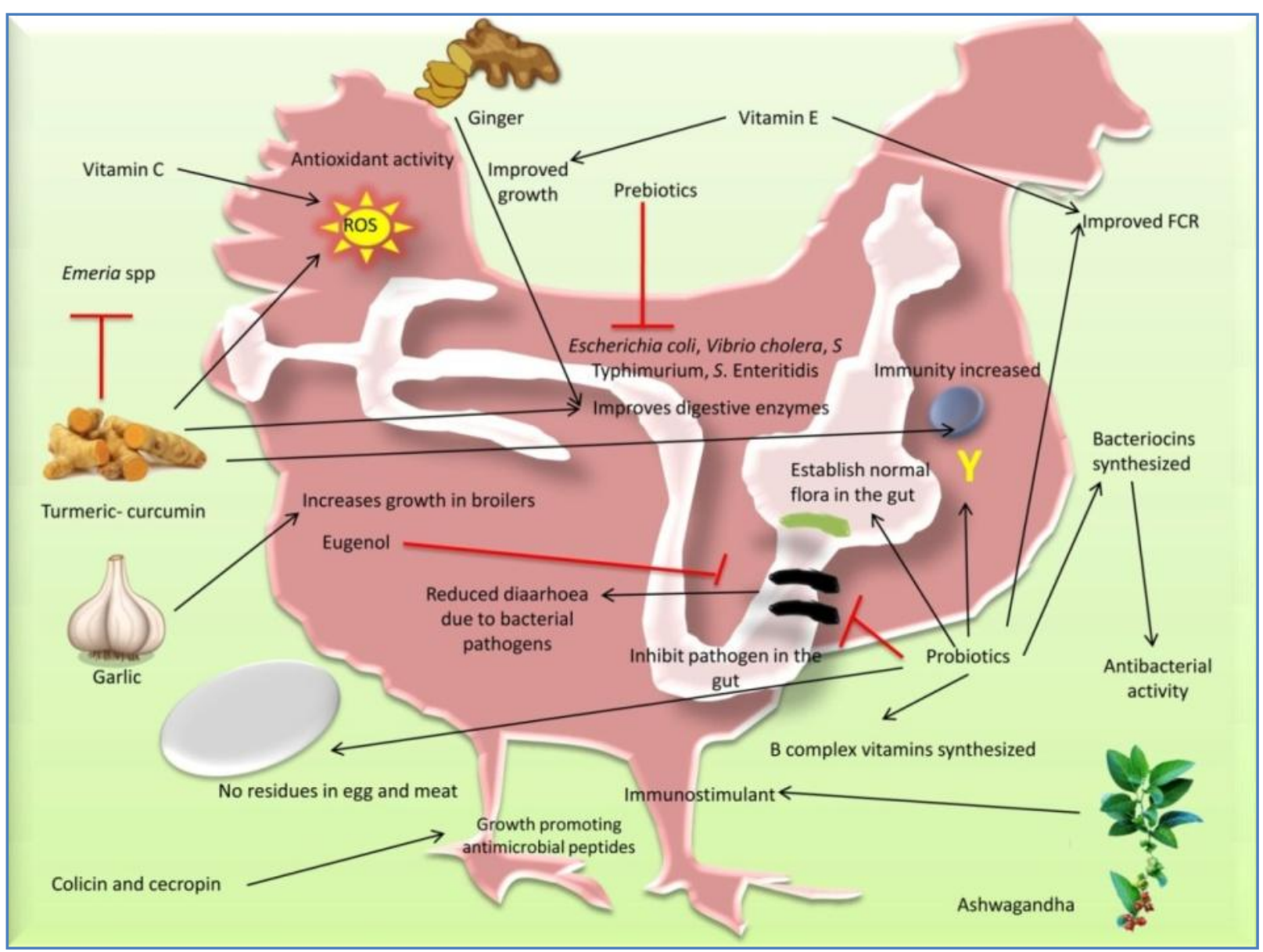

Figure 1 Beneficial effects of probiotics, prebiotics, vitamins, antimicrobial peptides and herbs as growth promoters in poultry.

The anti-parasitic property is very well studied especially of tannins (condensed tannins) which are more potent against gastro-intestinal parasites of sheep and goats. They also show potent anti-coccidial activity against chicken coccidia. In case of large animals (cattle, buffaloes) the phyto-compounds especially essential oils, exhibits methanogenic suppression effect (reduces the methane enteric methane production). Phytochemicals possesses antioxidant (both hydrophilic and lipophilic activity). Due their antioxidant activity these compounds are being used during stress periods including the heat stress conditions (Wei \& Shibamoto, 2007). Their antioxidant property could be helpful in improving the keeping quality of processed meats and also reduces the muscle drip loss during thawing of cold stored products (Windisch et al., 2008). These plant derived compounds shows typical flavors which could be exploited in human and pig foods. These compounds attract the consumers and increase their intake. Currently, essential oils are being used in preparation of icecream and others. However, their role as a flavoring agent in poultry production is still questionable. The dietary addition of active principles or its ingredient source increases the digestive process in the body. They were found to increase the secretion of digestive enzymes mainly trypsin, amylase and bile from the pancreas and liver respectively (Gopi et al., 2014a). This will help to improve the overall digestibility of the feed and feed efficiency. However, the higher level of incorporation of certain compounds especially polyphenols which lead to negative effects on digestive efficiency due to their ability to bind with the digestive enzymes. Staying with digestion these substances also increases the nutrient absorption capacity through increase in the intestinal villi length and crypt depth. They also alter the lipid metabolism in the system by inhibiting the activity of hepatic 3- hydroxy-3-methylglutaryl coenzyme A (HMG-CoA) reductase which reduces the cholesterol synthesis in the liver (Lee et al., 2004). This effect could be utilized for production of low cholesterol meat and eggs (Mohamed et al., 2012). Although, these compounds are generally recognized as safe (GRAS) their level of use is still debatable due to their unknown mechanisms for various activities and their possibility of deposition in the body.

Shift towards herbal medicine in the recent years is more due to advantages of these over chemical drugs which include reduced or zero toxicity, available naturally and possess ideal qualities as feed additive (Khan et al., 2010; Khan et al., 2012a). Plant parts such as herbs and spices are well known to have antimicrobial activities (Nychas \& Skandamis, 2003). 
The products derived from plant parts, specifically essential oils, are known to possess active ingredients that exhibit antimicrobial activity against bacteria, yeast and molds. Among the major groups of principle ingredients that impart antimicrobials property in their essential oils (EOs) include thymol, eugenol, saponins, flavonoids, carvacrol, terpenes and their precursors. Essential oils are volatile compounds due to which they possess characteristics fragrance of their origin and named after them (Oyen \& Dung, 1999).

The portion of plant from which essential oils can be derived include bulbs of onion and garlic, seeds of parsley, fruits, rhizomes, leaves of basil and tea plant, clove buds and other plant parts (Nychas \& Skandamis, 2003). For example, cinnamon barks having high levels of cinnamamic aldehyde and spices with a high level of eugenol are reported to have potent antimicrobial activity (Davidson \& Naidu, 2000). Essential oils from plants are reported to exhibit a broad antimicrobial spectrum against a wide range of bacterial and fungal agents (Tiwari et al, 2009). The antimicrobial property also depends on many biological factors (plant species, growing location and harvest stage), manufacturing processes (extraction/distillation) and conditions during storage (temperature, light, oxygen level and time). Thus, it remains a subject of investigation to identify and quantify the multitude of actions and claims improving feed efficiency and health status of poultry birds. The antimicrobial potential of essential oils also depends on the structural conformation of active ingredients and their concentration. Currently, herbs targeting bacterial quorum sensing disruption (Goossens, 2016) are gaining interest.

Antimicrobial property of essential oils such as thymol and carvacrol has been widely studied against range of bacteria such as L. monocytogenes, S. Typhimurium, and Vibrio parahaemolyticus (Karapinar \& Aktug, 1986; Tassou et al, 1995; Dhama et al., 2015a). Cinnamic aldehyde present in cinnamon oil have been found to exhibit antimicrobial action against a broad spectrum of bacteria such as L. monocytogenes, C. jejuni, and S. Enteritidis (Smith-Palmer et al, 1998). Eugenol present in clove essential oil has been widely studied for antimicrobials and antifungal activities (Deans et al., 1995; Smith-Palmer et al., 1998).

Use of EOs in poultry ration has been found to exert beneficial effect on body weight again and feed efficiency in broilers (Cross et al., 2002; Bampidis et al., 2005; Cabuk et al., 2006). Similarly, feeding of turmeric powder enhances the circulatory anti-oxidant defence and in turn immune system (Madpouly et al., 2011). Similarly, incorporation of garlic at 3\% level as feed additive has been found to enhance growth and performance of broiler chicks (Elagib et al., 2013). Incorporation of blends of different essential oils (lemon, basil, oregano, tea, etc.) in diet showed higher body weight gain (Khattak et al., 2014) in broilers, egg production with better feed conversion efficiency in laying quails (Cabuk et al., 2014). Recently, Salmonella Enteritidis and Salmonella Typhimurium has been found to be inactivated on skin of broiler birds using acidified sodium chlorite, trisodium phosphate or carvacrol (Karuppasamy et al., 2015, Yadav et al., 2016). Several plants and its derivates are extensively studied and used in poultry production including Aloe vera, Astragalus membranaceus, Ginger, Garlic, Noni, Onion, Turmeric and Thyme (Dhama et al., 2015b). These compounds have improved growth of broilers and also increased egg production of layers (Guo et al., 2004; Sunder et al., 2013; Sunder et al., 2014).

Natural resin acid composition (RAC), resinol is shown to possess antibacterial, antifungal and antiparasitic properties and its inclusion in feed reduced the percentage of gram positive population in vitro and modulated the intestinal microbiota besides improving the growth performance (Vuorenmaa, 2015). Zhang et al. (2012) observed higher growth performance in broilers fed fermented leaves of Ginkgo biloba along with Aspergillus niger. Many active principles of the herbs have been identified but mechanism of action for all has not been elucidated though for some it has been reported. Reports reveal that active principles of these herbs improves the normal microbiota of the gut thereby increasing the nutritional metabolism, absorption leading to better growth and production (Hashemi \& Davoodi, 2011). The increase in pancreatic enzymes (trypsin, chymotrypsin, amylase and lipase) activity due to feeding of turmeric, which is being attributed towards its active principle curcumin, has been seen (Khan et al., 2012b). Ginger increases secretion of enzymes like enterokinases and other enzymes important for digestion hence improving the digestion and metabolism of feed (Zhao et al., 2011). Similarly, addition of essential oils in feed has also improved secretion of digestive enzymes, increasing feed assimilation, overall activity of broilers were improved (AlKassie et al., 2011). These active principles also possess antioxidant properties thereby reducing the free radicals that are produced in the cells.

Herbal products not only possess antioxidant and digestive properties but also possess antimicrobial, antiparasitic and immunomodulating properties. Though immunostimulants are available they possess side effects warranting for a replacement hence herbal drugs can be a better alternative as an immunostimulant. There are established reports regarding the potential of flavonoids, lectins, polysaccharides, peptides and tannins as immunomodulators. Plants like Neem, Ashwagandha, Guduchi, Noni etc., possess immunomodulatory properties and its effects are well documented (AbdElslam et al., 2013; Bhatt et al., 2013; Latheef et al., 2013a; Latheef et al., 2013b; Tiwari et al., 2014a; Tiwari et al., 2014b). Herbs like cinnamon, nishyinda and black pepper has been reported to have promising growth promoter effects without exhibiting side effects in broilers (Chowdhury et al., 2009; Mode et al., 2009; Molla et al., 2012; Saminathan et al., 2013). Several herbal extracts exert antibacterial action when fed to poultry thereby preventing infectious diseases and enhancing growth of the poultry (Dhama et al., 2014b; Dhama et al., 2015b). Active ingredients of thyme namely thymol and carvacrol shows antimicrobial action especially against gram negative bacterial pathogens by 
penetrating the cell wall and causing damage to the cells by binding to the amine and hydroxylamine groups (Juven et al., 1994; Helander et al., 1998; Abd El-Hack et al., 2016). Curcumin has better action against Eimeria spp. that causes coccidiosis in poultry (Khalafallah et al., 2011).

Garlic increases phagocytic activity, production of interferon, interleukin and tumor necrosis factor $\alpha$ (Hanieh et al., 2010). Allicin, the bio-active component of garlic is reported to have the ability to infiltrate pathogen's cellular membranes and subsequent binding to key enzymes that results in blockage of cellular activities. Cineol and eucalyptol of eucalyptus oil provides relaxing effect on air sacs with appropriate ventilation during respiratory tract infections of bird (Nakielski, 2015). Comprehensive knowledge about the single active compound or their possible synergistic or negative effects is required for the solution oriented developments in herbal treatment (Heinzl \& Borchardt, 2015).

Several benefits of phytobiotics have been elucidated in past (Lee et al., 2004; Windisch et al., 2008; Salim, 2011; Gopi et al., 2014b; Dhama et al., 2014b; Karangiya et al., 2016) and summarized as below:

Salient benefits of phytobiotics are as follows:

1. Favorably alters the microbial population for maintaining the gut health

2. Reduces the insult of pathogenic bacteria, virus and parasites in the gut thereby reduces the need for anti-biotic therapy

3. Improves the body weight gain and feed efficiency

4. Increases the anti-oxidant defense against oxidative stress

5. Decreases cholesterol content through inhibiting hepatic enzyme activity

6. Stimulates the digestive enzyme secretions and nutrient absorption

7. Ameliorate the negative effects of heat stress

8. Environmental friendly insecticide and pesticide

\subsection{Antimicrobial peptides}

Antimicrobial peptides are also termed as host defense peptides which are present in all living organisms with an amino acid length of about 30 to 60 numbers. These peptides possess immunomodulatory and antimicrobial activity that can damage bacteria (by targeting cell membrane), virus and also fungus (Li et al., 2012; Parachin et al., 2012). Several of these antimicrobial peptides are identified and many were tested for their beneficial effects like growth promoter activity in poultry. Antimicrobial peptides like colicin and cecropin, especially cecropin A (1-11)-D (12-37)-Asn (CADN) has been studied as growth promoter in poultry which indicated that this could be a possible alternative for antibiotics as growth promoters (Liu-Fa \& Jian-Guo, 2012). In vitro studies indicated that, peptides isolated from chicken leukocytes have significantly inhibited L. monocytogenes and E. coli, Candida albicans (Harwig et al.,
1994). Bacteriocins, the non-toxic ribosomal antimicrobial peptides secreted by bacteria on their cell surface are observed to effectively reduce the campylobacter colonization in poultry (Svetoch \& Stern, 2010). These are new generation antimicrobials that may have potential to eradicate drug resistant bacteria. Nisin is the extensively studied bacteriocin for its use in food and therapeutic purpose in poultry (Joerger, 2003). Extraction of antimicrobial peptides from transgenic plants and application in poultry feed have been thought of (van t' Hof et al., 2001).

\section{Conclusions}

Antibiotics have ruled the poultry industry since several decades as a growth promoter. However, due to their over usage bacteria has developed resistance against them thus threatening human community with the emergence of extremely drug resistant pathogens. Hence, it is must to eliminate the use of antibiotics as growth promoters and search for alternatives that can aid in beneficial activities. Recently much research has been diverted towards the search for antibiotic alternatives and which in turn has resulted in the enhanced use of probiotics, prebiotics herbal drugs, etc. The use of probiotics, prebiotics, synbiotics, plant extracts and organic acid has many potential benefits including improvement in digestion and absorption of nutrients, modification of birds' metabolism, immunomodulation, and improvement in functioning and health of gut through exclusion and inhibition of pathogens in intestinal tract and improvement in safety of poultry products for human consumption. However, additional studies are still needed which would explore various combinations of these alternatives with specific target to enhance the production. Moreover, keeping in view the consumers demand for functional foods, efforts are being needed to explore further possibilities where alternatives of antibiotics in poultry production and poultry products with desirable attributes without affecting the welfare of the poultry birds, can be used.

\section{Conflict of interest}

Authors would hereby like to declare that there is no conflict of interests that could possibly arise.

\section{Acknowledgments}

All the authors acknowledge the support from their respective institutions and universities.

\section{References}

Abd El-Hack ME, Alagawany M, Farag MR, Tiwari R, Karthik K, Dhama K, Zorriehzahra J, Adel M (2016) Beneficial impacts of thymol essential oil on health and production of animals, fish and poultry: a review. Journal of Essential Oils (In http://dx.doi.org/10.1080/10412905.2016.1153002 
Abdel-Raheem SM, Abd-Allah SMS, Hassanein KMA (2012) The effects of prebiotic, probiotic and synbiotic supplementation on intestinal microbial ecology and histomorphology of broiler chickens. International Journal for Agro Veterinary and Medical Sciences 6: 277-289.

Abdelrahman W (2016) Effective strategies in the control of antibiotic resistance in poultry. International Hatchery Practice $30: 13-15$.

AbdElslam NM, Ahmad, S, Ullah R, Bibi A, Ahmad I, Mostafa MS, Khader JA (2013) Antibacterial assay of Withania somnifera. Journal of Pure and Applied Microbiology 7: 791-794.

Abudabos AM (2012) Optimal dietary phosphorus for broiler performance based on body weight group. Asian Journal of Animal and Veterinary Advances 7: 20-29.

Açkgöz Z, Bayraktar H, Altan Ö (2011) Effects of formic acid administration in the drinking water on performance, intestinal microflora and carcass contamination in male broilers under high ambient temperature. Asian-Australian Journal of Animal Sciences 24 : 96-102.

Adel Feizi (2013) Survey of Tiamulin+Oxytetracyclinein control of CRD complex due to La Sota vaccine in broiler chickens. European Journal of Zoological Research 2 : 45-49.

Adil S, Tufail B, Gulam AB, Masood S, Manzoor R (2010) Effect of dietary supplementation of organic acids on performance, intestinal histomorphology, and serum biochemistry of broiler chicken. Veterinary Medicine International 1-7. doi.org/10.4061/2010/479485.

Adil S; Magray SN (2012) Impact and manipulation of gut microflora in poultry: a review. Journal of Animal and Veterinary Advances 11: 873-877.

Afsharmanesh M, Pourreza J (2005) Effects of calcium, citric acid, ascorbic acid, vitamin D3 on the efficacy of microbial phytase in broiler starters fed wheat-based diets I. Performance, bone mineralization and ileal digestibility. International Journal of Poultry Science 4: 418-424.

Afzal R, Mughal SM, Munir M, Kishwar S, Qureshi R, Arshad M, Laghari MK (2010) Mycoflora associated with seeds of different sunflower cultivars and its managemenent. Pakistan Journal of Biology 42: 435-445.

Akyurek H, Ozduven ML, Okur AA, Koc F, Samli HE (2011) The effect of supplementing an organic acid blend and/or microbial phytase to a corn-soybean based diet fed to broiler chickens. African Journal of Agricultural Research 6: 642-649.

Al-Kassie GAM, Mohseen AM, Abd-Al-Jaleel RA (2011) Modification of productive performance and physiological aspects of broilers on the addition of a mixture of cumin and turmeric to the diet. Research Opinions in Animal and Veterinary Sciences 1: 31-34.

Alm EL Dein AK, Elhearon ER (2010) Antibiotic residue in eggs of laying hens following injection with gentamicin. New York Science Journal $3: 135-140$.

Amit-Romach E, SklanD, Uni Z (2004) Microflora ecology of the chicken intestine using $16 \mathrm{~S}$ ribosomal DNA primers. Poultry Science 83:1093-1098.

Anderson M, Macgowan A (2003) Development of the quinolones. Journal of Antimicrobial Chemotherapy 51:1-11.

Athar M, Ahmad MT (1996). Vet's Guide - manual of Veterinary Products. $2^{\text {nd }}$ Ed. World-wide Publisher, Pakistan.

Awad W, Gharee K, Bohm J (2008) Intestinal structure and function of broiler chickens on diets supplemented with a symbiotic containing enterococcus faecium and oligosaccharides. International Journal of Molecular Sciences 9: 2205-2216.

Bailey JS, Blankenship LC, Cox NA (1991) Effect of fructodigosaccharide on Salmonella colonization of the chicken intestine. Poultry Science 70: 2433-2438.

Bampidis VA, Christodoulou V, Florou-Paneri P, Christaki E, Chatzopoulou PS, Tsiligianni T, Spais, AB (2005) Effect of dietary dried oregano leaves on growth performance, carcass characteristics and serum cholesterol of female early maturing turkeys. British Journal of Poultry Science 46: 595-601.

Bhatt P, Shukla SK, Wani MY, Tiwari R, Dhama K (2013) Amelioration of chicken infectious anaemia virus induced immunosuppression by immunomodulator and haematinic supplementation in chicks.Veterinarski Arhiv 83: 639-652.

Billah M, MasudRana SM, Hossain MS, Ahamed SK, Banik S Hasan M (2015) Ciprofloxacin residue and their impact on biomolecules in eggs of laying hens following oral administration. International Journal of Food Contamination 2:13.

Blanch A (2015) European experiences with probiotics in poultry production. International Poultry Production 23 : 7-9.

Bliznakov EG (1978) Immunological senescence in mice and its reversal by coenzyme Q10. Mechanism of Ageing Development, 7: 189-197.

Boling SD, Webel DM, Mavromichalis I, Parsons CM, Baker DH (2000) The effects of citric acid on phytate phosphorus utilization in young chicks and pigs. Journal of Animal Science 78: 682-689.

Bohorquez D (2010) Nutritional influences on the ultrastructuraldevelopment of the small instestinal epithelium of the 
perinatalturkey embryo and poult. $\mathrm{PhD}$ thesis submitted to North Carolina State University, Raleigh.

Buddington KK, Donahoo JB, Buddington RK (2002) Dietary oligofructose and inulin protect mice from enteric and systemic pathogens and tumor inducers. Journal of Nutrition 132:472477.

Burt S (2004) Essential oils: Their antibacterial properties and potential applications in food- A review. International Journal of Food Microbiology 94: 223-253.

Cabuk M, Bozkurt M, Alcicek A, Akbap Y, Kucukyllmaz K (2006) Effect of a herbal essential oil mixture on growth and internal organ weight of broilers from young and old breeder flocks. South African Journal of Animal Science 36: 135-141.

Cabuk M, Eratak S, Alçicek A, Bozkurt M (2014) Effects of herbal essential oil mixture as dietary supplement on egg production in quail. The Scientific World Journal, 2014. Article ID 573470, DOI: 10.1155/2014/573470.

Catry B, Laevens H, Devriese, LA, Opsomer G, De Kruif A (2003) Antimicrobial resistance in livestock. Journal of Veterinary Pharmacology Therapy 26: 81-93.

Chowdhury R, Islam KM, Khan MJ, Karim MR, Haque MN, Khatun M, Pesti GM (2009) Effect of citric acid, avilamycin, and their combination on the performance, tibia ash, and immune status of broilers. Poultry Science 88:1616-1622.

Cross DE, Acamovic T, Deans SG, Cdevitt RM (2002) The effects of dietary inclusion of herbs and their volatile oils on the performance of growing chickens. British Journal of Poultry Science 43:33-35.

Cummings JH, Macfarlane GT (2002) Gastrointestinal effects of prebiotics. British Journal of Nutrition 87 : S145-151.

Davidson PM, Naidu AS (2000) Phyto-Phenols. In Naidu AS (Ed.), Natural Food Antimicrobial Systems, CRC. Boca Raton, FL, pp. 265-294.

Deans SG, Noble RC, Hiltunen R, Wuryani W, Penzes LG (1995) Antimicrobial and antioxidant properties of Syzygium aromaticum (L.) Merr\& Perry: impact upon bacteria, fungi and fatty acid levels in ageing mice. Flavour and Fragrance Journal 1:323-328.

de Oliveira, van der Hoeven-Hangoor, van de Linde IB, Montijn RC, van der Vossen JMBM (2014) In ovo inoculation of chicken embryos with probiotic bacteria and its effecton posthatch Salmonella susceptibility. Poultry Science 93: 818829.

Dhama K Mahendran M, Tomar S (2007) Probiotics and prebiotics: A safer way towards improving health and productivity in poultry. Poultry World 2: 28-32.
Dhama K, Mahendran M, Tomar S, Chauhan, RS (2008) Beneficial effects of probiotics and prebiotics in livestock and poultry: the current perspectives. Intas Polivet $9: 1-13$.

Dhama K, Verma V, Samant PM, Tiwari R Vaid RK, Chauhan RS (2011) Application of probiotics in poultry: Enhancing immunity and beneficial effects on production performances and health: A review. Journal of Immunology and Immunopathology 13: 1-19.

Dhama K, Tiwari R, Khan RU, Chakraborty S, Gopi M, Karthik K, Saminathan M, Desingu PA, Sunkara LT (2014a) Growth promoters and novel feed additives improving poultry production and health, bioactive principles and beneficial applications: The trends and advances- A Review. International Journal of Pharmacology 10 : 129-159.

Dhama K, Tiwari R, Chakraborty S, Saminathan M, Kumar A, Karthik K, Wani MY, Amarpal, Singh SV, Rahal A (2014b) Evidence based antibacterial potentials of medicinal plants and herbs countering bacterial pathogens especially in the era of emerging drug resistance: An integrated update. International Journal of Pharmacology 10: 1-43

Dhama K, Karthik K, Tiwari R, Shabbir MZ, Barbuddhe S, Malik SV, Singh RK (2015a) Listeriosis in animals, its public health significance (food-borne zoonosis) and advances in diagnosis and control: A comprehensive review. Veterinary Quarterly $35: 211-35$.

Dhama K, Latheef SK, Saminathan M, Samad HA, Karthik K, Tiwari, R, Khan RU, Alagawany M, Farag MR, Gazi MA, Laudadio V, Tufarelli V (2015b) Multiple beneficial applications and modes of action of herbs in poultry health and production - A review. International Journal of Pharmacology 11: $152-176$

Dibner JJ, Buttin P (2002) Use of organic acids as a model to study the impact of gut microflora on nutrition and metabolism. Journal of Applied Poultry Research 11:453-463.

Di Bartolomeo F, Startek JB,Van Den Ende W (2013) Prebiotics to fight diseases: Reality or fiction? Phytotheraphy Research 27:1457-1473.

Eidelsburger U, Kirchgessner M, Roth FX (1992) Influence of formic acid, calcium formate and sodium bicarbonate on $\mathrm{pH}$, concentration of carbonic acids and ammonia in different segments of the gastrointestinal tract: 8 liberation. Nutritive value of organic acids in piglet rearing. Journal of Animal Physiology 68: 20-32.

Elagib HAA, Elamin WIA, Elamin KM, Malik HEE (2013) Effect of dietary garlic (Allium sativum) supplementation as feed additive on broiler performance and blood profile. Journal of Animal Science Advances 3: 58-64. 
Folkers K, Shizukuishi S, Takemura K, Drzewoski J, Richardson P, Ellis J, Kuzell WC (1982) Increase in levels of $\mathrm{IgG}$ in serum of patients treated with coenzyme Q10. Research Communication in Chemistry Pathology and Pharmacology 38: 335-338.

Fuller R (1999) Probiotics for farm animals. Probiotics: A Critical Review 15-8: 15-22. ISBN: 1898486.

Fuller R (1992) History and development of probiotics. In: Fuller R (Ed.), Probiotics-The Scientific Basis. Chapman and Hall, London.

Gaggıa F, Mattarelli P, Biavati B (2010) Probiotics and prebiotics in animal feeding for safe food production. International Journal of Food Microbiology 141: S15-S28.

Ghiyasi M, Rezaei, Sayyahzadeh MH (2007) Effect of prebiotic (Fermacto) in low protein diet on performance and carcass characteristics of broiler chicks. International Journal of Poultry Science 6: 661-665.

Gibson GR (1999) Dietary modulation of the human gut microflorausing the prebiotics oligofructose and inulin. Journal of Nutrition 129: 1438-1441.

Goossens T (2016) Exploring quorum sensing to optimize gut health and performance. International Poultry Production 24 : 11-13.

Gopi M (2013) Bioenergetics role of coenzyme Q10 supplementation on broiler performance. M.V.Sc. Thesis, Tamil Nadu Veterinary and Animal Sciences University, Chennai, India.

Gopi M, Purushothaman MR, Chandrasekaran D (2014a) Effect of dietary coenzyme Q10supplementation on the growth rate, carcass characteristics and cost effectiveness of broiler fed with three energy levels. Springer Plus, Vol. 3 10.1186/21931801-3-518

Gopi M, Karthik K, Manjunathachar HV, Tamilmahan P, Kesavan M, Dashprakash M, Balaraju BL Purushothaman MR (2014b) Essential Oils as a Feed Additive in Poultry Nutrition. Advances in Animal and Veterinary Sciences 2: 1-7.

Gopi M, Dhinesh Kumar R, Elaiyaraja G, Karthik K, Manjunatha Char HV, Gautham K, Jaydip R, Purushothaman MR (2015) Dietary Essentiality I: Coenzyme Q10 Conditionally Essential-Review. Asian Journal of Animal and Veterinary Advances 10: 461-475.

Guo FC, Kwakkel RP, Williams BA, Li WK, Li HS, Luo JY, Li XP, Wei YX, Yan ZT, Verstegen MW (2004) Effects of mushroom and herb polysaccharides, as alternatives for an antibiotic, on growth performance of broiler Science 45: 684694.
Hamed DM, Hassan AMA (2013) Acids supplementation to drinking water and their effects on Japanese quails experimentally challenged with Salmonella enteritidis. Zoological Research $3: 15-22$.

Hassanpour H, Moghaddam AKZ, Khosravi M, Mayahi M (2013). Effects of synbiotic on the intestinal morphology and humoral immune response in broiler chickens. Livestock Science 153: 116-122.

Hanieh H, Narabara K, Piao M, Gerile C, Abe A, Kondo Y (2010) Modulatory effects of two levels of dietary Alliums on immune response and certain immunological variables, following immunization, in White Leghorn chicken. Animal Science Journal 81: 673-680.

Harwig SSL, Swiderek KM, Kokryakov, VN, Tan, L, Lee D, Panyutich EA, Aleshina, GM, Shamova OV, Lehrer RI (1994) Gallinacins - cysteine-rich antimicrobial peptides of chicken leukocytes. FEBS Letter 342: 281-285.

Hashemi SR, Davoodi H (2011) Herbal plants and their derivatives as growth and health promoters in animal nutrition. Veterinary Research Communications 35: 169-180.

Hassan HMA, Mohamed MA, Youssef AW, Hassan ER (2010) Effect of using organic acids to substitute antibiotic growth promoters on performance and intestinal microflora of broilers. Asian-Australian Journal of Animal Sciences 23: 1348-1353.

Heinzl I, Borchardt T (2015) Secondary plant compound to reduce the use of antibiotics? International Poultry Production $23: 15-17$.

Helander IM, Alakomi HL, Latva-Kala K, Mattila T, Sandholm Pol I, Smid EJ, Gorris LGM, Von Wright A (1998) Selected essential oil components on Gram negative bacteria. Journal of Agriculture and Food Chemistry 46: 3590-3595.

Hermans D, De Laet M (2014) Reaching genetic potential with medium chian fatty acids (MCFAs). International Poultry Production $22: 7-9$.

Hogenauer G, Mayer P, Drews J, (1981) The Macrophage Activating Potential of Ubiquinones. In: Folkers K,Yamagami T, Littaru GP (Eds.)., Biochem and Clinical Aspects of Coenzym Q. Elsevier Publishers, Netherlands, Pp: 325-334.

Huff GR, Huff WE, Farnell MB, Rath NC, Solis DLSF, Donoghu AM (2010) Bacterial clearance, heterophil function, and hematological parameters of transport-stressed turkey poults supplemented with dietary yeast extract. Poultry Science 89: 447-456.

Huyghebaert G, Ducatelle R, Van Immerseel F (2011) An update on alternatives to antimicrobial growth promoters for broilers. Veterinary Journal 187: 182-188. 
Jadhav K, Sharma KS, Katoch S, Sharma VK, Mane BG (2015) Probiotics in broiler poultry feeds: A Review. Journal of Animal Nutrition and Physiology 1: 4-16

Jiang HQ, Gong LM, Ma YX, He YH, Li DF, Zhai HX (2006) Effect of stachyose supplementation on growth performance, nutrient digestibility and caecal fermentation characteristics in broilers. British Poultry Science 47: 516-522.

Joerger RD (2003) Alternatives to antibiotics: bacteriocins, antimicrobial peptides and bacteriophages. Poultry Science 82: 640-647.

Juven BJ, Kanner J, Schved F, Weisslowicz H (1994) Factors that interact with the antibacterial action of thyme essential oil and its active constituents. Journal of Applied Bacteriology 76: 626-631.

Karangiya VK, Savsani HH, Patil SS, Garg DD, Murthy KS, Ribadiya NK, Vekariya SJ (2016) Effect of dietary supplementation of garlic, ginger and their combination on feed intake, growth performance and economics in commercial broilers. Veterinary World 9: 245-250.

Karapinar M, Aktug SE (1986) Sensitivity of some common food-poisoning bacteria to thyme, mint and bay leave. International Journal of Food Microbiology 3: 349-354.

Karuppasamy K, Yadav AS, Saxena GK (2015) Thermal inactivation of Salmonella Enteritidis on Chicken Skin Previously Exposed to Acidified Sodium Chlorite or TriSodium Phosphate. Journal of Food Science and Technology $52: 8236-8243$.

Kelly G (2008) Inulin-type prebiotics-A review: Part 1. Alternative Medicine Review 13: 315-329.

Khaksar V, Krimpen MV, Hashemipour H, Pilevar M (2012) Effects of Thyme Essential Oil on Performance, Some Blood Parameters and Ileal Microflora of Japanese Quail. Journal of Poultry Science 49: 106-110.

Khalafalla RE, Müller U, Shahiduzzaman M, Dyachenko V, Desouky AY, Alber G, Daugschies A (2011) Effects of curcumin (diferuloylmethane) on Eimeria tenella sporozoites in vitro. Parasitology Research 108: 879-886.

Khan RU (2011) Antioxidants and poultry semen quality. World's Poultry Science Journal 67: 297-308.

Khan RU, Durrani FR, Chand N (2010) Influence of feed supplementation with Cannabis sativa on quality of broilers carcass. Pakistan Veterinary Journal. 30: 34-38.

Khan RU, Naz S, Nikousefat Z, Tufarelli V, Laudadio V (2012a) Thymusvlugaris: alternative to antibiotics in poultry feed. World's Poultry Science Journal 68: 401-408.
Khan RU, Nikosefat Z, Tufarelli V, Naz S, Javdani M, Laudadio V (2012b) Garlic (Allium sativa) supplementation in poultry diet: effect on production and physiology. World's Poultry Science Journal 68: 417-424.

Khattak F, Ronchi A, Castelli P, Sparks N (2014) Effects of natural blend of essential oil on growth performance, blood biochemistry, cecal morphology, and carcass quality of broiler chickens. Poultry Science 93: 132-137.

Khksar V, Golian A, Kermanshahi H, Movasseghi, Jamshidi A (2008) Effect of prebiotic fermacto on gut development and performance of broiler chickens fed diet low in digestible amino acids. Journal of Animal Veterinary Advances 7: 251257.

Kidder DE, Manners MJ (1978) Digestion in the pig. Bath UK: Kingstone Press.

Kil DY, Kwon WB, Kim BG (2011) Dietary acidifiers in weanling pig diets: a review. Revista Colombiana de Ciencias Pecuarias 24: 231-247.

Kim YY, Kil DY, Oh HK, Han IK (2005) Acidifier as an alternative material to antibiotics in animal feed. AsianAustralasian Journal of Animal Sciences 18: 1048-1060.

Kodimalar K, Rajini RA, Ezhilvalavan S, Sarathchandra G (2014) A survey of chlortetracycline concentration in feed and its residue in chicken egg in commercial layer farms. Journal of Biosciences 39 : 425-431.

Latheef SK, Dhama K, Wani MY, Samad HA, Barathidasan R, Tiwari R, Singh SD, Rai RB (2013a) Ameliorative effects of four herbs (Withania somnifera, Tinospora cordifolia, Azadirachta indica and E care Se herbal) on the pathogenesis of chicken infectious anaemia virus. International Journal of Current Research 5: 2327-2331.

Latheef SK, Dhama K, Wani MY, Samad HA, Tiwari R, Singh SD (2013b) Ameliorative effects of Withania somnifera, Azadirachta indica, Tinospora cordifolia and E care Se herbal preparations on chicken infectious anaemia virus induced haematological changes in chicks and their live body weights. South Asian Journal of Experimental Biology 3: 172-182.

Lee KW, Ewerts H, Beynen AC (2004) Essential oils in broiler nutrition. International Journal of Poultry Science 3: 738-752.

Lee SH, Lillehoj HS, Dalloul RA, Park, DW, Hong, YH, Lin JJ (2007) Influence of pediococcus-based probiotic on coccidiosis in broiler chickens. Poultry Science 86: 63-66.

Li X, Liu LQ, Xu C (2008). Effects of supplementation of fructo-oligosaccharide and/or Bacillus subtilis to diets on performance and intestinal microflora in broilers. Archivf ur Tierzucht 51:64-70. 
Li YM, Xiang Q, Zhang QH, Huang YD, Su ZJ (2012) Overview on the recent study of antimicrobial peptides: origins, functions, relative mechanisms and application. Peptides 37: 207-215.

Lin H, Jiao HC, Buyse J, Decuypere E (2006) Strategies for preventing heat stress in poultry. World's Poultry Science Journal 62: 71-86.

Liu-Fa W, Jian-Guo H (2012) Dose-response effects of an antimicrobialp peptide, a cecropin hybrid, on growth performance, nutrient utilisation, bacterial counts in the digesta and intestinal morphology in broilers. British Journal of Nutrition 108: 1756-1763.

Luangtongkum T, Morishita TY, Ison AJ, Huang S, McDermott PF, Zhang Q (2006) Effect of conventional and organic production practices on the prevalence and antimicrobial resistance of Campylobacter spp. in poultry. Applied and Environmental Microbiology 72 : 3600-3607.

Madej JP, Stefaniak T, Bednarczyk M (2015) Effect of in ovodelivered prebiotics and synbiotics on lymphoid-organs morphology in chickens. Poultry Science 94: 1209-1219.

Madpouly, HM, Saif, MA, Hussein AS (2011) Curcuma longa for protecting chicks against Newcastle disease virus infection and immunosuppressive effect of Marek's disease viral vaccine. International Journal of Virology 7: 176-83.

Madsen KL, Cornish A, Soper P, McKaigney C, Jijon H, Yachimec C, Doyle J, Jewell L, De Simone C (2001) Probiotic bacteria enhance murine and human intestinal epithelial barrier function. Gastroenterology 121: 580-591.

Mahmood K, Rahman SU, Hussain RZ, Abbas T, Arif KJ and Mahmood F (2014) World's Poultry Science Journal70: 865879 .

Mani-Lopez E, García HS, López-Malo A (2012) Organic acids as antimicrobials to control Salmonella in meat and poultry products. Food Research International 45: 713-721.

Mansour SA, Bakr RFA, Mohamed RI, Hasaneen NM (2011) Larvicidal activity of some botanical extracts, commercial insecticides and their binary mixtures against the housefly, MuscaDomestica L. The Open Toxinology Journal 4: 1-13.

Mayer EA (1994) The physiology of gastric storage and emptying. In: physiology of the gastrointestinal Tract. 3rd ed. New York: Lippincott Raven Press; 1994. Pp.929-76

Martinez M, McDermott P, Walker R (2006) Pharmacology of the fluoroquinolones: a perspective for the use in domestic animals. Veterinary Journal 172: 10-28.
McDowell LR (ed.) (1989) Vitamins in animal nutrition Comparative aspects to human nutrition. Vitamin A and E. Academic Press, London. pp. 10-52: 93-131.

McKee JS, Harrison PC (1995) Effects of supplemental ascorbic acid on the performance of broiler chickens exposed to multiple concurrent stressors. Poultry Science 74: 17721785.

Mode SG, Funde ST, Waghmare SP, Kolte AY (2009) Effect of Herbal Immunodulator on Body weight gain in immunosuppressed broiler birds. Veterinary World 2: 269-270.

Mohamed AB, Rubaee MAM, Jalil AQ (2012) Effect of ginger (Zingiber officinale) and blood serum parameters of broilers. International Journal of Poultry Science 11(2): 143-146.

Molla MR, Rahman MM, Akter F, Mostofa M (2012) Effect of Nishyinda, black pepper and cinnamon extract as growth promoter in broilers. The Bangladesh Veterinary Journal, 29: 69-77.

Mookiah SS, Sieo CC, Ramasamy K, Abdullah N, Ho YW (2014) Effects of dietary prebiotics, probiotic and symbiotic on performance, caecal bacterial populations and caecal fermentation concentrations of broiler chickens. Journal of Science Food and Agriculture 94: 341-348.

Mroz Z (2005) Organic acids as potential alternatives to antibiotic growth promoters for pigs. Advances in Pork Production 16:169-182.

Murali N, Kumar-Phillips GS, Rath NC, Marcy J, Slavik MF (2012) Effect of marinating chicken meat with lemon, green tea and turmeric against food borne bacterial pathogens. International Journal of Poultry Science 11: 326-332.

Naeem M, Khan K, Rafiq S (2006) Determination of residues of quinolones in poultry products by high performance liquid chromatography. Journal of Applied Sciences $6: 373-379$.

Nakamura Y, Nosaka S,Suzuki M, Nagafuchi S, Takahashi T, Yajima T, Takenouchi-Ohkubo N, Iwase T, Moro I (2004) Dietary fructo-oligosaccharides up-regulate immunoglobulin A response and polymeric immunoglobulin receptor expression in intestines of infant mice. Clinical and Experimental Immunology 137:52-58.

Nakielski A (2015) Treating respiratory tract infections in poultry with the use of herbs. International Poultry Practice 23 :7-9.

Narimani-Rad M, Nobakht A, Shahryar HA, Kamani J, Lotfi A (2011) Influence of dietary supplemented medicinal plants mixture (ziziphora, oregano and peppermint) on performance and carcass characterization of broiler chickens. Journal of Medicinal Plants Research 5: 5626-5629. 
Niness KR (1999) Inulin and oligofructose: What are they? Journal of Nutrition 129:1402-1406.

NRC (1994) Nutrient requirements of poultry, National Academy Press, Washington, D.C., Ninth Edition. 1994.

Nychas GJE, Skandamis PN (2003) Antimicrobials from herbs and spices. In Roller S (Ed.), Natural antimicrobials for the minimal processing of foods, CRC. Boca Raton, FL, pp. 177 200.

Oluwasile BB, Agbaje M, Ojo OE, Dipeolu MA (2014) Antibiotic usage pattern in selected poultry farms in Ogun state. Sokoto Journal of Veterinary Sciences $12: 45-50$.

Oyen LPA, Dung NX (1999) Plant resources of South-East Asia No. 19. Essential-oil plants. Backhuys Publishers.

Pal P, Chander U (1999) Probiotics benefits. Poultry International October issue, Pp: 40-44.

Parachin NS, Mulder KC, Viana AAB, Dias SC, Franco OL (2012) Expression systems for heterologous production of antimicrobial peptides. Peptides 38: 446-456.

Patterson JA, Burkholder KM (2003) Prebiotic feed additives: Rationale and use in pigs. In: Ball RA (Ed.), Proceedings of the 9th international symposium on Digestive Physiology in Pigs, Banff, Canada: University of Alberta 1: 319-331.

Pedroso A (2009) Which came first: The egg or its microbiota? Pages 1-4 in Poultry Informed Professional. University of Georgia, Athens.

Peric L, Zikic D, Lukic M (2009) Application of alternative growth promoters in broiler production. Biotechnology Animal Husbandry 25: 387-397.

Persoons D, Dewulf J, Smet A, Hermanb, L, Heyndrickx M Martel A, Catry B, Butayec P, Haesebrouckc F (2012) Antimicrobial use in Belgian broiler production. Preventive Veterinary Medicine 105: 320-325.

Prescott JF, Baggot JD (1993) Antimicrobial Therapy in Veterinary Medicine, 2nd edn., Iowa State University Press, Iowa, USA. pp. 564-565.

Ratcliff J (2000) Antibiotic bans a European perspective. In: Proceedings of the $47^{\text {th }}$ Maryland Nutrition Conference for Feed Manufacturers. March 2224 pp. 135152.

Rinttila T, Apajalahti J ( 2013) Intestinal microbiota and metabolites- implications for broiler chicken health and performance. Journal of Applied Poultry Research 22: 647658.

Sahin K, Onderci M, Sahin N, Gursu MF, Kucuk O (2003) Dietary vitamin $\mathrm{C}$ and folic acid supplementation ameliorates the detrimental effects of heat stress in Japanese quail. Journal of Nutrition133: 1882-1886.

Saleh AA, Eid YZ, Ebeid TA, Ohtsuka A, Hayashi K (2012) The modification of the muscle fatty acid profile by dietary supplementation with Aspergillus awamori in broiler chickens. British Journal of Nutrition 108: 1596-1602.

Salim AB (2011) Effect of some plant extracts on fungal and aflatoxin production. International Journal of Academic Research 3: 116-120.

Saminathan M, Rai RB, Dhama K, Tiwari R, Chakraborty S, Amarpal, Ranganath GJ, Kannan K (2013) Systematic review on anticancer potential and other health beneficial pharmacological activities of novel medicinal plant Morindacitri folia (Noni). International Journal of Pharmacology 9: 462-492

Seema A, Johri TS (1992) Probiotics in poultry feeds. Poultry Guide 29: 51-58.

Sherman PM, Ossa JC, Johnson-Henry K (2009) Unravelling mechanisms of action of probiotics. Nutrition Clinical Practice 21: $10-14$.

Smith-Palmer A, Stewart J, Fyfe L (1998) Antimicrobial properties of plant essential oils and essences against five important food-borne pathogens. Letters in Applied Microbiology 26 : 118-22.

Sunder J, Jeyakumar S, Sujatha T, Kundu A (2013) Effect of feeding of morical: A herbal based supplement on production and egg quality in Japanese quail. Advances in Animal and Veterinary Science 1: 157-160.

Sunder J, Sujatha T, Pazhanivel N, Kundu A, Kundu MS (2014) Effect of Morindacitri folia fruit juice and lactobacillus acidophilus on broiler duodenal morphology. Advances in Animal and Veterinary Science 2: 28-30.

Sunkara LT, Achanta M, Schreiber NB, Bommineni YR, Dai G (2011) Butyrate enhances disease resistance of chickens by inducing antimicrobial host defense peptide gene expression. PLoS One 6.10.1371/journal.pone 0027225.

Sunkara LT, Jiang W, Zhang G (2012) Modulation of antimicrobial host defense by free fatty acids. PLosONE 7.10.1371/journal.pone. 0049558 .

Svetoch, EA, Stern, NJ (2010) Bacteriocins to control Campylobacter spp. in poultry-A review. Poultry Science 89:1763-1768

Stanton, TB (2013) A call for antibiotic alternatives research. Trends in Microbiology. 21: 111-113. 
Świątkiewicz S, Arczewska-Włosek A, Józefiak D (2014) Immunomodulatory efficacy of yeast cell products in poultry: a current review. World's Poultry Science Journal 70: 57-68.

Tang AL, Shah NP, Wilcox G, Walker KZ, Stojanovska L (2007) Fermentation of calcium fortified soya milk with Lactobacillus: effects on calcium solubility, isoflavone conversion and production of organic acids.Journal of Food Science 72: 431-436.

Tassou CC, Drosinos EH, Nychas GJ (1995) Effects of essential oil from mint (Menthapiperita) on Salmonella Enteritidis and Listeria monocytogenes in model food systems at 4 degrees and 10 degrees C. Journal of Applied Bacteriology 78: 593-600.

Tiwari BK, Valdramidis VP, O'Donnell CP, Muthukumarappan K, Bourke P, Cullen, PJ (2009) Application of natural antimicrobials for food preservation. Journal of Agricultural Food Chemistry 57: 5987-6000.

Tiwari R, Chakraborty S, Saminathan M, Dhama K, Singh SV (2014a) Ashwagandha (Withania somnifera): Role in safeguarding health, immunomodulatory effects, combating infections and therapeutic applications: A review. Journal of Biological Science 14: 77-94.

Tiwari R, Verma AK, Chakraborty S, Dhama K, Singh SV (2014b) Neem(Azadirachtaindica) and its potential for safeguarding health of animals and humans: A review. Journal of Biological Science 14: 110-123

Van Loo J, Cummings J, Delzenne N, Englyst H, Franck A, Hopkins M, Kok N, Macfarlane G, Newton D, Quigley M, Roberfroid M, van VlietT, van den Heuvel E (1999) Functional food properties of non-digestible oligosaccharides: A consensus report from ENDO project (DGXII AIRII-CT941095). British Journal of Nutrition, 81:121-132.

van't Hof W, Veernan ECI, Helmerhorst EJ, Amerongen AVN (2001) Antimicrobial peptides: properties and applications. Biological Chemistry 382:597-619

Van den Bogaard AE, Stobberingh EE (2000) Epidemiology of resistance to antibiotics. Links between animals and humans. International Journal of Antimicrobial Agents 14: 327-335.

Vuorenmaa J (2015) Natural resin acid contributes to improved broiler performance. International Poultry Production 23 : 1719.

Wang JP, Yoo JS, Lee JH, Zhou TX, Jang HD, Kim HJ, Kim IH ( 2009) Effects of phenyllactic acid on production performance, egg quality parameters, and blood characteristics in laying hens. Journal of Applied Poultry Research 18:203209.

Wei A, Shibamoto T (2007) Antioxidant activities and volatile constituents of various essential oils. Journal of Agricultural and Food Chemistry $55: 1737-1742$.

Windisch W, Schedle K, Plitzner C, Kroismayr A (2008) Use of phytogenic products as feed additives for swine and poultry. Journal of Animal Sciences 86: 140-148. doi:10.2527/jas.2007-0459.

Yadav AS, Saxena GK, Saxena VK, Kataria JM, Juneja VK (2016) Thermal inactivation of Salmonella Typhimurium on Dressed Chicken Skin Previously Exposed to Acidified Sodium Chlorite or Carvacrol. Food Control DOI 10.1016/j.foodcont.2016.02.014

Yamamoto M, Saleh F, Tahir M, Ohtsuka A, Hayashi K (2007) The effect of Koji feed (fermented distillery byproduct) on the growth performance and nutrient metabolizability in broiler. Journal of Poultry Science 44: 291-296.

Yang Y, Iji PA, Choct M (2009) Dietary modulation of gut microflora in broiler chickens: a review of the role of six kinds of alternatives to in-feed antibiotics. World's Poultry Science Journal 65: 97-114.

Yang YPA, Choct M (2009) Dietary modulation of gut microflora in broiler chickens: a review of the role of six kinds of alternatives to in-feed antibiotics. World's Poultry Science Journal. 5: 97-103.

Yegani M, Korver, DR (2008) Factors affecting intestinal health in poultry. Poultry Science 87: 2052-2063

Zha C, Cohen AC (2014) Effects of anti-fungal compounds on feeding behavior and nutritional ecology of tobacco budworm and painted lady butterfly larvae. Entomology, Ornithology and Herpetology 3:120.

Zhang X, Cao F, Sun, Z, Yu W, Zhao L, Wang G, Wang T (2012) Effect of feeding Aspergillus niger fermented Ginkgo biloba-leaves on growth, small intestinal structure and function of broiler chicks. Livestock Science 147: 170-180.

Zhao X, Yang ZB, Yang WR, Wang Y, Jiang SZ, Zhang GG (2011) Effects of ginger root (Zingiber officinale) on laying performance and antioxidant status of laying hens and on dietary oxidation stability. Poultry Science 90: 1720-1727 